AGRICULTURE AND BIOLOGY JOURNAL OF NORTH AMERICA

ISSN Print: 2151-7517, ISSN Online: 2151-7525, doi:10.5251/abjna.2011.2.10.1326.1335

(C) 2011, ScienceHuß, http://www.scihub.org/ABJNA

\title{
Genetic variability studies in West African okra (Abelmoschus caillei)
}

\author{
${ }^{1 *}$ AdeOluwa,O.O. and ${ }^{2}$ Kehinde, O.B. \\ ${ }^{1}$ Vegetable / Floriculture Department, National Horticultural Research Insitute, Ibadan, \\ Nigeria,08026894007, olusolaodutayo@yahoo.co.uk \\ ${ }^{2}$ Department of Plant Breeding and Seed Technology, University of Agriculture, Abeokuta, \\ Nigeria, 08035169778. \\ *Corresponding author olusolaodutayo @ yahoo.co.uk
}

\begin{abstract}
A collection of 35 accessions of West African Okra (Abelmoschus caillei) were evaluated for variability in 20 morphological and agronomic traits (qualitative and quantitative traits).Genotypic and phenotypic variances, genotypic (GCV) and phenotypic coefficients of variation (PCV), heritability, genetic advance of the characters were calculated. The accessions demonstrated wide variability for all characters evaluated. Variation was expressed in all qualitative traits studies except in leaf and petal colour. Phenotypic variances were generally higher than their respective genotypic variances thus revealing the role of environmental factors. High PCV and High GCV were observed for pod yield per plant and peduncle length, respectively. Very low heritability estimate was observed for number of ridges per fruit $(7.1 \%)$. Moderately high heritability estimate $(78.99 \%)$ was observed for peduncle length; moderately high PCV and GCV $35.71 \%$ and $31.74 \%$, respectively but low genetic advance of $1.99 \%$.
\end{abstract}

Keywords: Abelmoschus caillei, Accessions, Variation, Heritability

\section{INTRODUCTION}

Okra is one of the most important and widely grown vegetable crops grown throughout the tropic and subtropics. It is a member of the family Malvaceae and genus Abelmoschus.

The study by Martin et. al (1981) distinguished two major classes of okra, the conventional and unconventional type. The conventional Abelmoschus esculentus which is a native of Asia, and the unconventional Abelmoschus callei which is a native of Africa. A. caillei (A. Chev) is an unconventional okra type which grows naturally in many parts of West Africa. West African Okra grows naturally in Nigeria, especially in the marginal lands along the roadsides, backyard farms, and wastelands (Adeniyi, et al., 2007).It is bigger in size than the conventional okra, Abelmoschus esculentus (L.) Moench. It is an annual, high yielding and hardy erect plant with numerous cultivars which vary in period of maturity, degree of branching, plant height, pigmentation of various parts of the plant, pod shape and size. West African Okra contained 194 chromosomes as against 130 of the conventional okra, thus constituting a new okra species (Ariyo, 1993). Okra provides an important input of vitamins and mineral salts, including calcium; which are often lacking in diet of developing countries. It is a nutritious vegetable containing $86.1 \%$ water, $2.2 \%$ protein, $0.2 \%$ fat, $9.7 \%$ carbohydrate, $1.0 \%$ fiber and $0.8 \%$ ash (Saifullah and Rabbani, 2009).

The value of a germplasm collection depends not only on the number of accessions it contains, but also upon the diversity present in those accessions (Ren et al., 1995). Characterization and quantification of genetic diversity and information on the genetic diversity within and among closely related crop varieties is essential for a rational use of plant genetic resources. Diversity based on phenotypic and morphological characters usually varies with environments and evaluation of traits requires growing the plants to full maturity prior to identification. Omonhinmin and Osawaru (2005) reported that high degree of wide morphological variation exist among accessions of okra, especially in West African type.

Genetic variability is a very important component of plant breeding which is a major tool being used to cope with the ever-increasing pressure of an expanding world population on food production (Ariyo, 1990). 
Agric. Biol. J. N. Am., 2011, 2(10): 1326-1335

Information on genetic variability of different characters of a crop and about the useful genes in each accession which is properly evaluated to identify the potential accessions is necessary prior to breeding programme for improvement in any crop.

It has been a widely accepted axiom in earlier that evaluation is an essential preliminary to utilization. Breeding aims change rapidly, hence evaluation needs to be adaptive. Only the breeder can recognize which characters need to be evaluated, or at least checked, in his own environment. In effecting improvement in yield, selection of superior genotypes is based on the outward appearance (phenotype) which is subject to variation due to fluctuating environmental factors. Under similar environmental conditions, any progress in a breeding programme depends on the magnitude of genetic variability in a population and the extent to which the desirable traits are heritable (heritability). Therefore, it is necessary to evaluate the genetic stocks acclimatized to local conditions (Osekita and Akinyele, 2008).

Ariyo (1993) working on genetic diversity among 30 (thirty) accessions of West African Okra observed a large genetic variability among the accessions. The large amount of genetic variability observed supports the opinion that this okra type constitutes a separate species. Within species variation among 30 African genotypes was found to be considerably large based on phenotypic assessment (Ariyo, 1993). Pigmentation and fruit characteristics were important components of the genetic variability among the accessions; the number of pods per plant, pod weight, length of peduncle, petiole length and days to maturity were found to be most effective (Ariyo, 1993).

As okra production play a significant role in the economy as other annual crops, more attention should be accorded to the selection of high yielding cultivars for seed and edible fruits.

Therefore, this study aims at investigating the variability in okra varieties obtained from different locations in South West and Middle Belt of Nigeria and, to measure the degree of genetic diversity in the accessions of Abelmoschus caillei with the view to formulating a breeding strategy for improvement and selection.

\section{MATERIALS AND METHODS}

Thirty - five genotypes of West African Okra (Abelmoschus callei) obtained from locations of the
South West and Middle Belt Nigeria were used for the experiment (Table 1). Table 1: West African Okra accessions used and
their sources

\section{ACCESSIONS SOURCE}

Acc 1

Acc 2

Acc 3

Acc 4

Acc 5

Acc 6

Acc 7

Acc 8

Acc 9

Acc 10

Acc 11

Acc 12

Acc 13

Acc 14

Acc 15

Acc 16

Acc 17

Acc 18

Acc 19

Acc 20

Acc 21

Acc 22

Acc 23

Acc 24

Acc 25

Acc 26

Acc 27

Acc 28

Acc 29

Acc 30

Acc 31

Acc 32

Acc 33

Acc 34

Acc 35
Ikere-Ekiti, Ekiti State

Ilaro, Ogun State

Amoke, Benue State

Ise-Ekiti, Ekiti State

Abeokuta, Ogun State

Ikere-Ekiti, Ekiti State

Omuo-Ekiti, Ekiti State

Ipetumodu, Osun State

Ibadan, Oyo State

Ibadan, Oyo State

Ipetumodu, Osun State

Iyin-Ekiti, Ekiti State

Okitipupa, Ondo State

Ila-Orangun, Osun State

Odigbo, Ondo State

Ipetumodu, Osun State

Abeokuta, Ogun State

Ila-Orangun, Osun State

Ipetumodu, Osun State

Ado-Ekiti, Ekiti State

Abeokuta, Ogun State

Ikere-Ekiti,Ekiti State

Ila-Orangun, Osun State

Osi-Ekiti, Ekiti State

Amoke, Benue State

Ado-Ekiti, Ekiti State

Abeokuta, Ogun State

Orun-Ekiti, Ekiti State

llawe-Ekiti, Ekiti State

Ado-Ekiti, Ekiti State

Ilesa, Osun State

Abeokuta, Ogun State

Ila-Orangun, Osun State

Odeda, Ogun State

Abeokuta, Ogun State
The experiment was conducted during the late cropping season (July - January) of the year 19992000 in the COLPLANT farm, at the University of Agriculture, Alabata, Abeokuta, Ogun State,Nigeria.

The genotypes were grown in a Randomised Complete Block Design (RCBD). Each accession was sown in single-row plot to minimise environmental variations associated with large plots and in three replications. Two seeds were sown per hole by hand dibbing. Each row was $6 \mathrm{~m}$ long with a 
row-row distance of $1 \mathrm{~m}$. The plant was spaced $50 \mathrm{~cm}$ within rows to give 13 plants per row i.e. $100 \mathrm{~cm}$ by $50 \mathrm{~cm}$ planting distance. Three weeks later, plants were thinned to one plant per stand. Weeding was carried out manually at 3 WAP, 6 WAP and at 9 WAP. A compound fertilizer, N.P.K. 12:12:17 was applied at the rate of $60 \mathrm{kgN} / \mathrm{ha}$ in two doses, first at three weeks after planting and then at flowering.

Ultracide 40EC insecticide was applied forthnightly at the rate of $2 \mathrm{mls}$ in 15 litres of water to control insect pests.

Six competitive plants per row were selected and utilized for data collection. Visual observations and measurements were done. Data collection were on the following characters: days to flowering (d), stem pubescence, stem colour, leaf colour, petiole colour, petal colour, position of fruit on main stem, fruit colour, fruit length $(\mathrm{cm})$, length of peduncle $(\mathrm{cm})$, number of ridges per fruit, fruit pubescence, internode distance $(\mathrm{cm})$, weight of 100 seeds(g), number of seeds per pod, number of pods per plant, number of branches per plant, days to maturity (d), pod yield per plant $(\mathrm{g})$ and plant height $(\mathrm{cm})$.

The mean values of the data collected were used for analysis of variance and covariance of each pair of character studied. Data were also used to calculate range, arithmetic mean, genotypic and phenotypic variance, the genotypic coefficient of variation, phenotypic coefficient of variation, heritability estimates in broad sense and expected genetic advance(Burton 1952;Johnson et al, 1955.

The genotypic and phenotypic correlation coefficients were calculated using variance and covariance components in accordance to the procedure outlined by Miller et al., (1958) as presented in Table 2.

\section{Table 2: The analysis of variance (ANOVA) showing expected means squares}

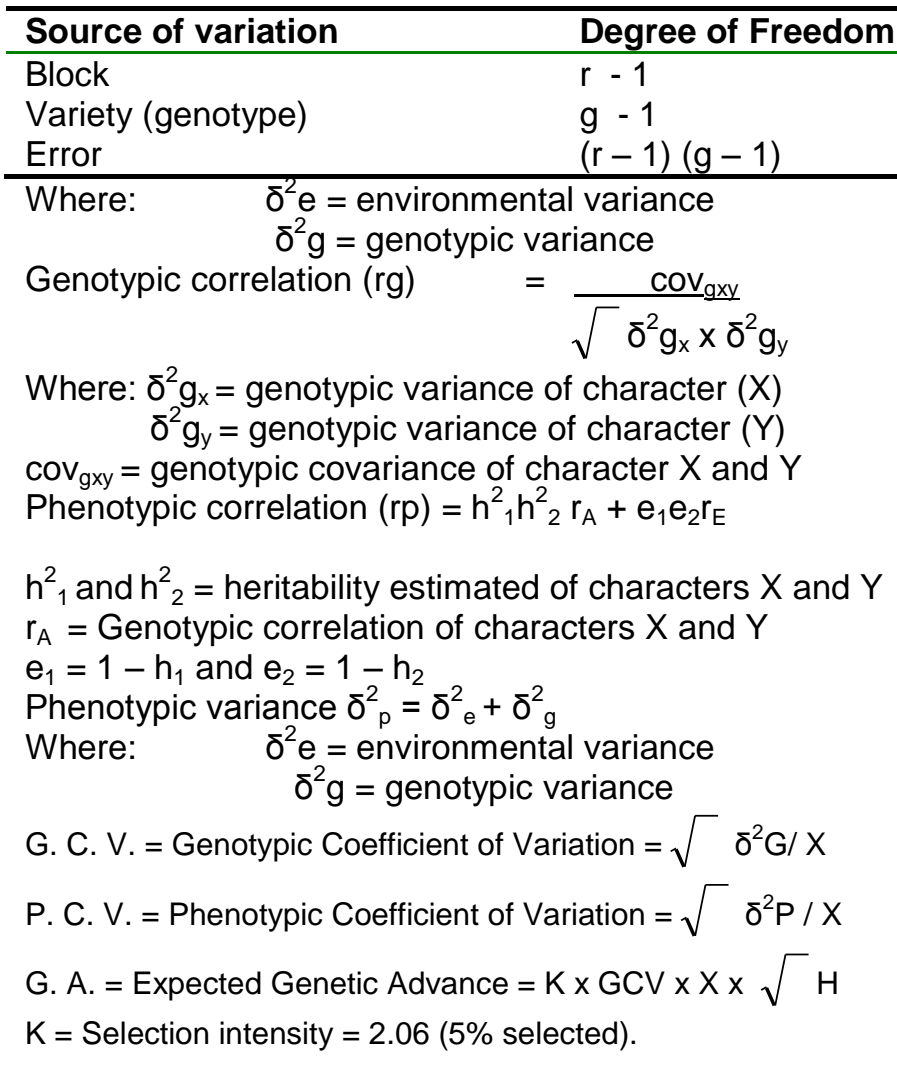

\section{RESULTS}

Qualitative characters: There was uniform green leaf colour and yellow petal colour for all the accessions. The genes controlling these character traits are probably dominant genes, thus no variation was expressed amongst the 35 accessions (Table 3 ). 
Agric. Biol. J. N. Am., 2011, 2(10): 1326-1335

Table 3: Qualitative characters observed among the accessions

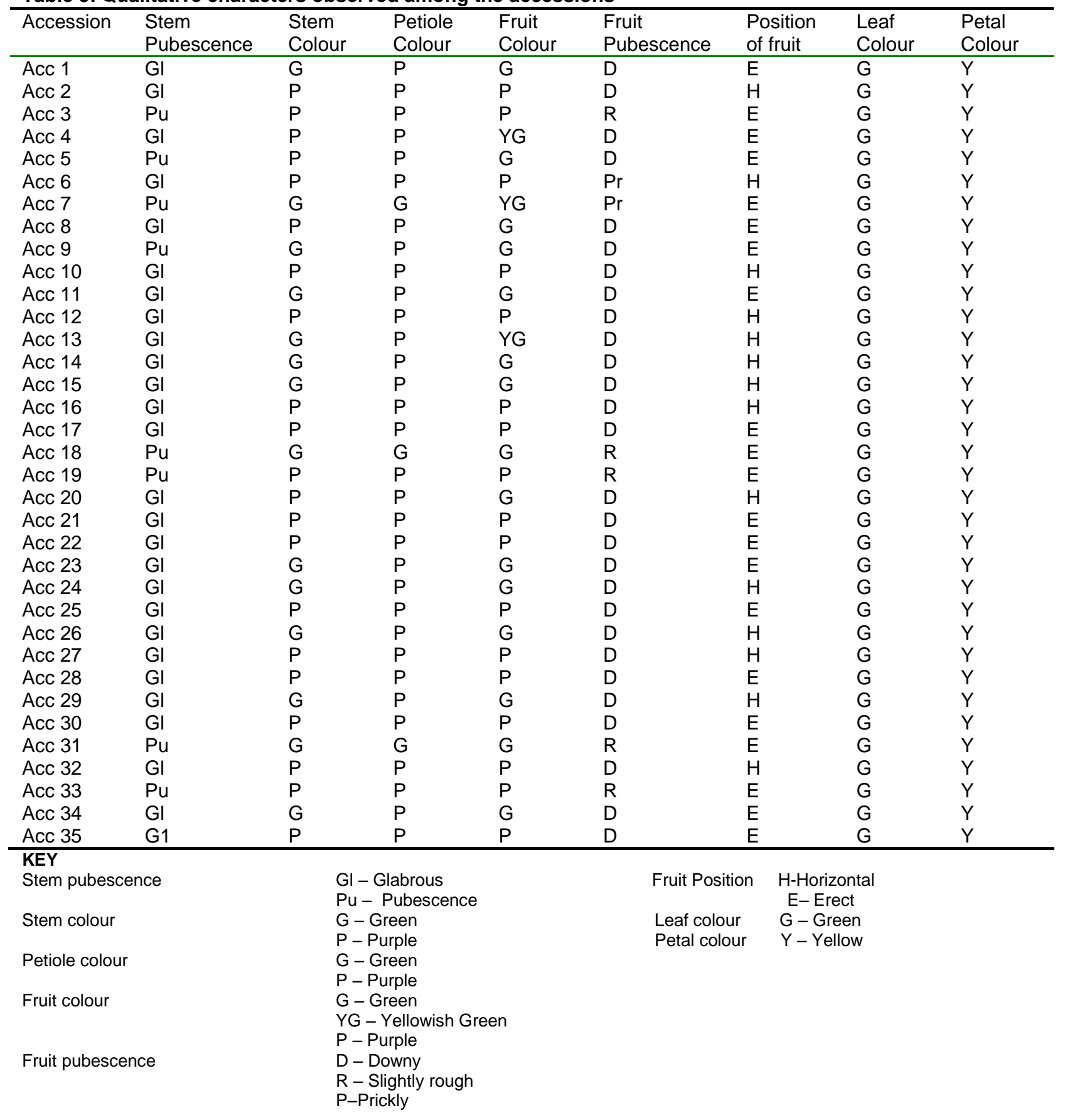


Table 4: Analysis of Variance for 12 traits in West African Okra, the values are mean square

\begin{tabular}{|c|c|c|c|c|c|c|c|c|c|c|c|c|c|}
\hline $\begin{array}{l}\text { Source } \\
\text { of } \\
\text { Variatio } \\
\text { n }\end{array}$ & $\overline{D f}$ & $\begin{array}{l}\text { Days to } \\
\text { Flowering } \\
\text { (d) }\end{array}$ & $\begin{array}{l}\text { Days to } \\
\text { Maturity } \\
\text { (d) }\end{array}$ & $\begin{array}{l}\text { Fruit } \\
\text { Lengt } \\
\mathrm{h}(\mathrm{cm})\end{array}$ & $\begin{array}{l}\text { No of } \\
\text { ridges } \\
\text { per fruit }\end{array}$ & $\begin{array}{l}\text { No of } \\
\text { branches } \\
\text { per plant }\end{array}$ & $\begin{array}{l}\text { Internode } \\
\text { distance } \\
\text { (cm) }\end{array}$ & $\begin{array}{l}\text { Peduncl } \\
\text { e length } \\
\text { (cm) }\end{array}$ & $\begin{array}{l}\text { Plant } \\
\text { height } \\
\text { (cm) }\end{array}$ & $\begin{array}{l}\text { No of } \\
\text { pods } \\
\text { per } \\
\text { plant }\end{array}$ & $\begin{array}{l}\text { Pod yield } \\
\text { per plant } \\
\text { (g) }\end{array}$ & $\begin{array}{l}\text { No of } \\
\text { seeds } \\
\text { per pod }\end{array}$ & $\begin{array}{l}\text { Weight } \\
\text { of } 100 \\
\text { seeds } \\
\text { (g) }\end{array}$ \\
\hline $\begin{array}{l}\text { Replicati } \\
\text { on }\end{array}$ & 2 & $192.267^{\star *}$ & $71.267^{*}$ & ${ }_{*}^{6.564^{*}}$ & $37.829^{\star *}$ & $4.867^{*}$ & 0.025 & 0.711 & ${ }_{* \star}^{6134.443}$ & $52.314^{* \star}$ & $\underbrace{4550.215^{*}}_{*}$ & 5.400 & 0.029 \\
\hline Varieties & 34 & $862.290^{* *}$ & $782.792^{* *}$ & ${ }_{*}^{5.805^{*}}$ & 1.850 & $39.119^{\star *}$ & $3.875^{\star *}$ & $3.843^{* *}$ & $\underset{* \star}{4286.182}$ & $12.711^{* *}$ & ${ }_{*}^{1413.070^{*}}$ & $977.015^{\star *}$ & $1.280^{* *}$ \\
\hline Error & 104 & 24.590 & 15.306 & 0.342 & 1.505 & 1.141 & 0.635 & 1.313 & 708.285 & 5.618 & 647.075 & 69.371 & 0.017 \\
\hline
\end{tabular}

${ }^{*},{ }^{* *}$ significant at $5 \%$ and $1 \%$ levels respectively 
Agric. Biol. J. N. Am., 2011, 2(10): 1326-1335

Qualitative characters studied among the thirtyfive $A$. caillei accessions.:

\section{Variable}

\section{Character expressed and frequency}

Stem pubescence

Glabrous 27, Pubescence 8

Stem colour

Petiole colour

Fruit colour

Green 3

Fruit pubescence

Position of fruit

Leaf colour

Purple 21, Green 14

Green 15, Purple 17, Yellowish

Downy 28, Rough 5, Prickly 2

Horizontal 14, Erect 21

Green 35

Petal colour

Yellow 35

Quantitative Characters: Analysis of variance for thirty-five West African Okra varieties is presented in Table 4. The varieties showed highly significant differences in all of the characters considered except in number of ridges per fruit.

Estimates of mean, standard error, range, phenotypic and genotypic variances are presented in Table 5.

The highest genotypic variance was observed in plant height followed by number of seeds per pod and days to flowering. Genotypic variances of days to maturity (255.829) and pod yield per plant (255.322) were very close in magnitude. This suggests that days to maturity of the West African Okra plant has direct influence on the yield of the crop plant. The longer the days to maturity, the increase in the pod yield. Genotypic variance of number of ridges per fruit was the lowest $(0.115)$.

Results of Phenotypic and genotypic coefficients of variation, heritability and genetic advance are presented in Table 6.

Maximum phenotypic and genotypic coefficient of variation was exhibited by pod yield per plant $(46.53 \%)$ followed by number of pods per plant $(35.96 \%)$, and peduncle length (31.74\%) respectively. The least phenotype and genotypic coefficients of variation were exhibited by 100 - seed weight $(12.06 \%)$ and numbers of ridges per fruit (3.78\%) respectively.

Phenotypic and genotypic coefficients of variation were very close in magnitude for number of pods per plant $(35.96 \%)$ and peduncle length (35.71\%) followed by 100 - seed weight $(12.06 \%)$ and days to maturity (12.45\%) and numbers of pods per plant and number of seeds per pod respectively i.e. $19.57 \%$ and $19.59 \%$.

Heritability estimate in broad sense was highest for 100 - seed weight (96.12\%) followed by days to

maturity (94.36\%). It was however very low for number of ridges per fruit $(7.10 \%)$ and low for pod yield per plant $(28.29 \%)$ and number of pods per plant $(29.62 \%)$.

The highest genetic advance was observed for plant weight $(44.63 \%)$, followed by days to flowering $(33.00 \%)$, number of seeds per pod $(32.31 \%)$, days to maturity (32.01\%) and pod yield per plant $(17.51 \%)$. The remaining characters however exhibited very low genetic advance.

\section{DISCUSSION}

Among the eight qualitative characters studied, there exists relationship between the stem colour of the accessions and the fruit colour as well as their petioles colour. The relationship was stronger between the stem colour and the fruit colour than between the stem colour and petiole colour of the accessions. The same trend was observed between the stem pubescence and the fruit pubescence. These may probably be as a result of one gene controlling the pair of traits of stem and fruit colour, and stem and fruit pubescence in the various accessions. This was also reported by Singh et al. (1974) in Akinyele and Osekita, (2006) that investigated variation in okra species and found out that a large number of okra characters such as pigment colour and spines on the fruit surfaces are inherited in a simple fashion, suggesting that these characters are controlled by relatively few genes.

For the leaf and petal colour, the genes controlling these traits are probably dominant genes as no variation was expressed amongst the accessions.

The analysis of variance showed a wide range of variation observed for all the characters studied. The non-significant differences observed in the number of ridges per fruit indicate that the genetic components of the parental material are intact. It follows, therefore, that any improvement sort must be directed at the other characters except number of ridges per fruit.

Also, high significant genotypic and phenotypic variances observed indicated that the genotypes utilized are of diverse genetic background thereby providing a large scope for selection. Phenotypic variances were generally higher than their respective genotypic variances thus revealing the role of environmental factors in altering the expressions of genotypes. Similar trend of variation was reported by Ariyo (1990) and Sood et al., (1993).

The difference between the phenotypic and their corresponding genotypic variances was not too large 
Agric. Biol. J. N. Am., 2011, 2(10): 1326-1335

in the characters studied except for number of ridges per fruit, number of pods per plant and pod yield per plant (Table 5). The significant differences revealed by the attributes of yield studied may be due to environmental influences on the parental genetic constitution. This large difference amongst the three characters was as a result of environmental variance. This environmental variance affected the development of pod i.e. environmental effects on plants, their population per plant as well as the eventual pod yield per plant. There was an interaction between the pods produced per plant and pod yield per plant. Environmental effect reflected on the number of ridges per fruit.

High PCV and High GCV observed for pod yield per plant and peduncle length respectively implied an interaction between the two characters and high genetic determination for peduncle length (Table 6). This was also reported by Magar and Madrap (2009) where in the study of variability among 41 genotypes of okra (Abelmoschus esculentus (L.) Moench), the GCV and PCV were of higher magnitude for fruit yield per plant followed by number of fruits per plant, node at which first flower appear, plant height and fruit weight.

Very low heritability observed for number of ridges per fruit $(7.10 \%)$ as well as low heritability for pod yield per plant $(28.29 \%)$ and number of pods per plant $(29.62 \%)$ reveals the ineffectiveness of direct selection for these characters (Table 6). This suggests that the genotypes cannot be improved through direct selection for these traits. However, the conspicuously higher difference between the phenotypic coefficient of variation and genotypic coefficient of variation of the characters pod yield per plant and number of pods per plant, (Table 6) was largely due to the strong influence of the environment during the developmental stages of the crop. The interaction of the genotypes with the environment in utilization of the natural phenomenal necessitated the wide difference in these characters which are often regarded as the major components of yield (Akinyele and Osekita, 2006). The potentials for all the genotypes to have more pods per plant would be enhanced if fresh pods were harvested promptly to give room for more branches to be formed. This will, in turn, enhance the overall yield of the genotypes. The fact that number of branches per plant, internode distance, peduncle length, plant height, number of pods per plant, pod yield per plant, number of seeds per pod had high to moderate PCV and GCV, heritability estimates and genetic advance, (Table 6) suggested that they were controlled by additive gene effects. Selection can therefore be based with certainty on their phenotypic expressions for crop and seed yield improvement. Low genotypic variance and genotypic coefficients of variation as well as low heritability estimates and genetic advance was observed for number of ridges per fruit. Wakhande et al., (1995) reported that additive gene action was predominant for days to flowering, ridges per fruit, while non-additive and over dominance genetic variances were recorded for yield, fruit yield per plant and fruit diameter and length in conventional okra. Low genotypic variance and genotypic coefficients of variation as well as low heritability estimates and genetic advance was observed for number of ridges per fruit. However, no differences between genotypic (12.09) and phenotypic (12.45) coefficient of variation, high heritability estimate (94.36) observed for days to maturity accompanied with moderately high genetic advance (32.01\%) indicated almost no environmental influences upon the expression of this character. The same was observed in days to flowering. The lowest coefficients of variation recorded for days to maturity and days to flowering are an indication of a measure of productivity. It also suggests numerical classification and that the various okra varieties could be discriminated. This is supported by the findings of Osekita and Ariyo (2000), Ariyo (1989), Sneath and Sokal (1973) and Ariyo and Odulaja (1991). The genotypes had longer days to maturity as a result of the longer vegetative growth phase, which they have to undergo before flowering.

Low difference between genotypic and phenotypic coefficient of variation indicates low environmental effect upon the expression of seeds per fruit and weight of 100 seeds $(\mathrm{g})$, (Table 6), which had high heritability with medium genetic advance, though that of weight of 100 seeds $(\mathrm{g})$ was low(1.31) indicated selection might be effective for these traits.

Genetic parameters for yield and yield contributing characters of West African Okra showed wide variation. All the characters studied showed considerable variations for genotypic and phenotypic coefficient of variation. Singh et al. (1998) observed higher genotypic and phenotypic coefficient of variation for plant height and fruits per plant of okra. Chandra et al. (1996) found higher genotypic and phenotypic coefficient of variation for branches per plant, fruit weight and fruit yield per plant in okra. Dash and Mishra (1995) reported that variance for seeds per fruit differed significantly in okra 
genotypes. Patil et al. (1996) found considerable genotypic and phenotypic coefficient of variation for days to first flowering, number of fruits per plant, individual fruit weight and fruit yield per plant.

Moderately high heritability estimate (78.99\%) observed for peduncle length which also has moderately high phenotypic and genotypic coefficient of variation i.e. $35.71 \%$ and $31.74 \%$ respectively with the difference relatively low, was not followed by high genetic advance (1.99\%). The low genetic advance could mainly be due to non-fixable (non - additive) gene effects i.e. dominance and epistatic effect of genes as suggested by Johnson et al., 1955 and Panse et al., 1957. It is suggested that such traits can be improved by method of recurrent selection.

Table 5: Mean, Standard Error, Range, Phenotypic and Genotypic Variances of 12 West African Okra characters

\begin{tabular}{|c|c|c|c|c|}
\hline Characters & Means \pm S.E & Range Min - Max & $\begin{array}{l}\text { Phenotypic } \\
\text { Variances }\end{array}$ & $\begin{array}{l}\text { Genotypic } \\
\text { Variances }\end{array}$ \\
\hline Days to Flowering (d) & $99.99 \pm 0.84$ & $58.00-135.0$ & 303.82 & 279.23 \\
\hline Days to Maturity (d) & $132.31 \pm 0.66$ & $93.00-143.67$ & 271.14 & 255.83 \\
\hline Fruit Length (cm) & $9.54 \pm 0.99$ & $7.07-12.90$ & 2.16 & 1.82 \\
\hline Number of ridges per fruit & $8.97 \pm 0.21$ & $7.33-10.67$ & 1.62 & 0.12 \\
\hline Number of branches per plant & $15.59 \pm 0.18$ & $8.33-22.67$ & 13.80 & 12.66 \\
\hline Internode distance (cm) & $6.31 \pm 0.13$ & $4.10-8.92$ & 1.72 & 1.08 \\
\hline $\begin{array}{l}\text { Peduncle length }(\mathrm{cm}) \\
\text { Plant height }(\mathrm{cm})\end{array}$ & $\begin{array}{l}3.42 \pm 0.09 \\
168.60 \pm 4.50\end{array}$ & $\begin{array}{l}155-6.11 \\
65.19-210.83\end{array}$ & $\begin{array}{l}1.49 \\
1900.92\end{array}$ & $\begin{array}{l}1.18 \\
1192.63\end{array}$ \\
\hline Number of pods per plant & $7.86 \pm 0.40$ & $3.67-12.67$ & 7.98 & 2.36 \\
\hline $\begin{array}{l}\text { Pod yield per plant }(\mathrm{g}) \\
\text { Number of seeds per pod }\end{array}$ & $\begin{array}{l}64.56 \pm 4.30 \\
88.77 \pm 1.41\end{array}$ & $\begin{array}{l}29.75-103.79 \\
50.67-138.00\end{array}$ & $\begin{array}{l}902.41 \\
371.92\end{array}$ & $\begin{array}{l}255.33 \\
302.55\end{array}$ \\
\hline Weight of 100 seeds $(\mathrm{g})$ & $5.49 \pm 0.02$ & $4.23-6.56$ & 0.44 & 0.42 \\
\hline
\end{tabular}

Table 6: Phenotypic and Genotypic Coefficients of Variation, Heritability and Expected Genetic Advance as Percentage of Mean for 12 West African Okra Characters

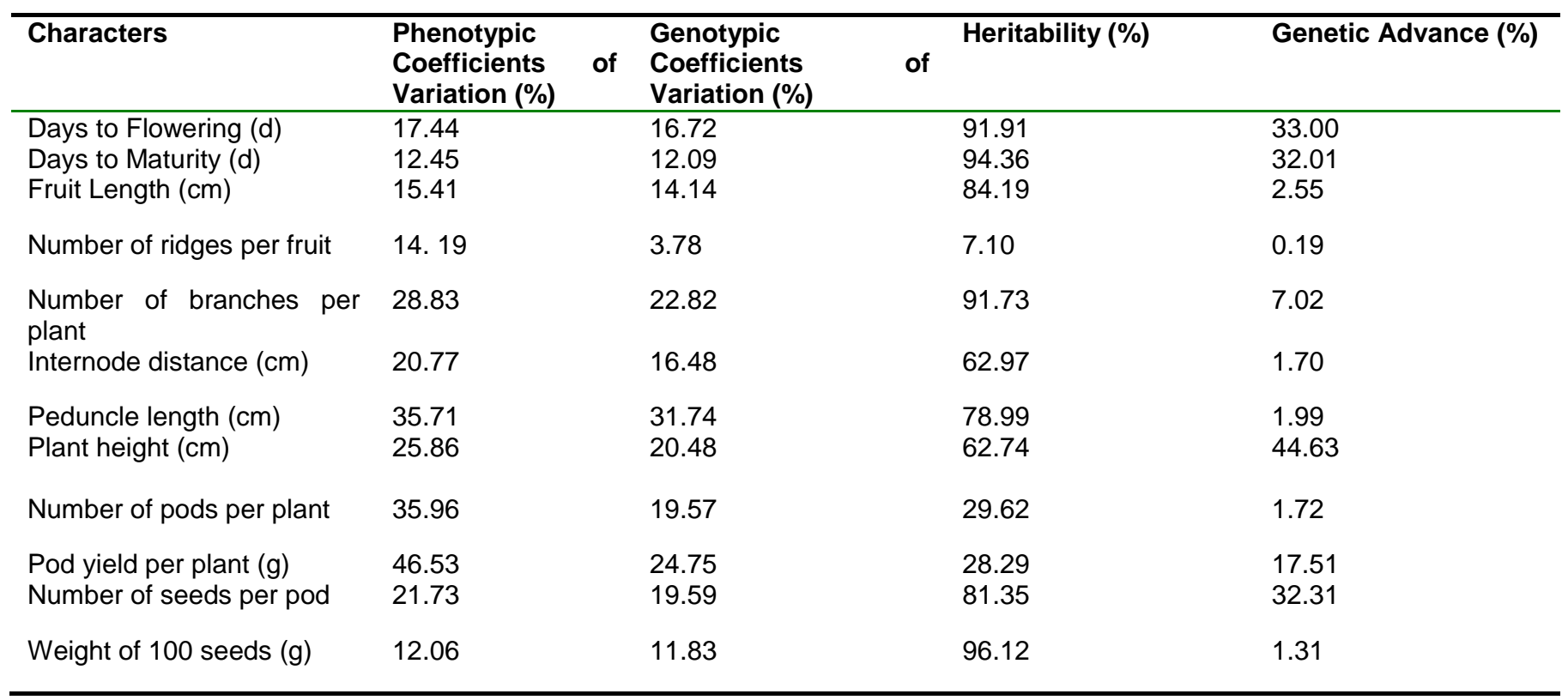

${ }^{*},{ }^{* \star}$ Significant at $5 \%$ and $1 \%$ level of probability respectively 


\section{CONCLUSIONS}

Variability observed in this study for all traits were indicative of the differences in the genetic make-up of the cultivars considered thus offering better chances and large scope for selection.

Phenotypic variances were generally higher than their respective genotypic variances thereby revealing the role of environmental factors on genotype expression of the various accessions. This gave rise to the variability observed for all traits of the accessions.

Also, there was interaction between character traits of High PCV and High GCV and these PCV and GCV percentages are necessary as a guide in selection and breeding programmes. However, the genetic advance for each of the traits should be considered in the course of breeding to ensure success in breeding and crop improvement.

\section{REFERENCES}

Adeniji, O.T, Kehinde, O.B., Ajala, M.O. and Adebisi, M.A. (2007). Genetic Studies on seed yield of West African Okra ( Abelmoschus caillei) (A chev.) Stevels). Journal of Tropical Agriculture, 45 (1-2):36-41, 2007.

Akinyele, B.O. and Osekita, O.S. (2006). Correlation and path coefficient analyses of seed yield attributes in okra (Abelmoschus esculentus (L.)Moench). African Journal of Biotechnology Vol. 5 (14), pp. 13301336.http://www.academicjournals.org/AJB.

Ariyo O.J. (1989). Variation and heritability of fifteen characters in okra (Abelmoschus esculentus (L.) Moench). Trop. Agric. J. Trinidad 67:1990 pp. 215-216.

Ariyo, O.J. (1990). Variation and heritability of fifteen characters in okra (Abelmoschus esculentus (L) Moench) Trop. Agric. 67: 3, $213-21 \overline{6}$.

Ariyo, O.J. (1993). Genetic diversity in West African Okra (Abelmoschus caillel) (A chev.) Stevels -Multivariate analysis of morphological and agronomic characteristics. Genetics Res. and Crop Evol. 40: 25 32.

Ariyo, O.J. and Odulaja, A. (1991). Numerical analysis of variation among accessions of okra (Abelmoschus esculentus (L.) Moench), Malvaceae. Ann. Bot., 67: 527-531.

Burton, G.W. (1952).Quantitative inheritance in grasses. Proc. $6^{\text {th }}$ Int. Grass Bd Cong 1:277-283.

Chandra, D.E.O., Singh, K.P., Panda, P.K. and Deo, C. (1996). Genetic variability, correlation and path analysis in okra. Environment and Ecology 14: 2, 315 -319 .
Dash, G. B. and Mishra, P. K. (1995). Variation and character association of fruit yield and its component characters in okra. Current Agricultural Research, 8(34), 123-127.

Jeyepandi, A. and Balakrishan, R. (1992). Genetic variability in okra. India Journal of Hort. 49: 2, 197199.

Johnson, R.W., Robinson, H.F. and Comstock, R.E. (1955) Genotypic and phenotypic correlation in soyabean and their implication in selection. Agron. J 47:477-480.

Magar, R. G. and Madrap, I. A. (2009). Genetic variability, correlations and path co-efficient analysis in okra (Abelmoschus esculentus L.) International Journal of Plant Sciences (Muzaffarnagar) .Vol. 4 No. 2 pp. 498501. ISSN : 0973-1547.

http://www.hhindagrichorticulturalsociety.com.

Martin, F.W. (1982). Okra, potential multiple purpose crop for the temperate zones and tropics. Econ. Bot. 36, 340.

Martin, F.W., Rhodes, A.M., Manuel, O., and Diaz, F. (1981). Variation in okra. Euphytica 30: 699-705.

Miller, P.A., Williams, J.C., Robinson, H.F. and Cormstook, R.E. (1958). Variance and covariances in upland cotton and their implication in selection. Agron. J. 50: 126-131.

Omonhinmin, C.A., and Osawaru M.E. (2005). Morphological characterization of two species of Abelmoschus: Abelmoschus esculentus and Abelmoschus caillei. Genet. Resour. Newsl. 144: 5155.

Osekita, O.S. and Ariyo, O.J. (2000). Variation and inter character association in the segregating of populations arising from two cases of okra (Abelmoschus esculentus (L.) Moench). Moor J., 1: 76-78.

Osekita, O.S. and B.O. Akinyele, (2008). Genetic analysis of quantitative traits in ten cultivars of okraAbelmoschus esculentus (Linn.) moench. Asian J. Plant Sci., 7: 510-513. DOI:10.3923/ajps.2008.510.513URL: http://scialert.net/abstract/?doi=ajps.2008.510.513

Panse, V.G. and Sukatme P.V. (1957). Statistical methods for agricultural workers. ICAR, New Delhi $371 \mathrm{pp}$.

Patil, Y. B., B.B. Madalageri, B.D. Biradar and R.M. Hosmani (1996). Variability studies in okra (Abelmoschus esculentus L. Moench.). Karnataka Journal of Agricultural Science 9(2), 289-293.

Ren J, McFerson J, Kresovich RLS and Lamboy WF (1995). Identities andRelationships among Chinese Vegetable Brassicas as Determined by Random Amplified Polymorphic DNA Markers. 120(3): 548-555. 
Saifullah, M. and Rabbani, M. G. (2009) . Evaluation and Characterization of Okra (Abelmoschus esculentus L. Moench.) Genotypes. SAARC J. Agri., 7 (1), 92-99.

Singh, K., Malik, Kallo, Y.S. and Mehrota, N. (1974). Genetic variability and correlation in Bhindi Abelmoschus esculentus ((L) Moench) Veg. Sci. (India) 1, $47-54$.

Singh, A. K., Singh, K.P., and Singh,V. P., (1974). Genetic Analysis of Induced Mutation of Okra Abelmoschus esculentus ((L) Moench Veg. Sci. 25(2), $174-177$.
Sneath, P.H.A. and R.R. Sokal, (1973). Numerical Taxonomy. 1st Edn., W.H. Freeman San Francisco, USA., ISBN-10: 0716706970, pp: 573

Sood, S., Prem, S.A. and Sharma, S.K. (1993). Correlation and path coefficient analysis in bhindi (Abelmoschus esculentus (L) Moench). Him. J. Agric. Res. 19:1.2.3247.

Wankhade, R.V., Kale, P.B. and Dod, V.N. (1995). Genetic of earliness, yield and fruit characters in okra. PKV Res. J. 19:2, 117 - 120. 